\section{Hospital Cost Containment}

Hospital cost containment legislation seems dead to everyone in Washington except officials at the Department of Health, Education and Welfare. The House defeated the bill last November, 234-166. Even if the Administration successfully convinces the Senate to accept mandatory cost containment in debating the MedicareMedicaid reimbursement bill, it is unlikely that the House would reconsider its position. And Congressional sources indicate that Senate Finance Committee Chairman Russell B. Long (D, LA) is not willing to support cost containment in a trade-off for Administration support of his catastrophic health insurance bill. But HEW remains committed to reducing the rate of hospital inflation by the use of controls. It may resort to regulatory authority even more than it did last year to make up for the time lost fighting for cost containment legislation.

In his State of the Union message, President Carter called for action on his hospital cost containment bill, calling it "the single most important piece of legislation that the Congress can pass to demonstrate its commitment to fighting inflation."

\section{Health Planning}

A three-year extension of the Health Planning Act was signed into law. The measure resulted from compromises and concessions.

\section{National Health Insurance}

The Senate Finance Committee out- lined a catastrophic insurance bill, but postponed decisions on several controversial issues. The only action in the House was a joint hearing by the Ways and Means and Commerce health subcommittees.

\section{Child Health \\ Assurance Program}

The House passed a bill December 11 but tacked on some amendments that will prove controversial. A Senate version was approved by the Finance Committee in July, but no floor action has been taken.

\section{Health Maintenance Organiza- tions}

The House Commerce Health Subcommittee voted to allow about 100 more health maintenance organizations to participate in a new program of Medicare reimbursement that would pay HMOs $95 \%$ of what fee-for-service providers in the same area are charging for Medicare services.

The proposal includes a more liberal definition of a prepaid health plan than the one favored by the Department of Health, Education, and Welfare. Under the subcommittee version Blue Cross-Blue Shield HMOs, which are not federally qualified because they "experience-rate" enrollees and do not seat members on governing boards, could participate in the generous reimbursement program.

\section{Medicare-Medicaid Reimbursement Reform}

The Senate Finance Committee proposed a bill making numerous adjust. ments in the reimbursement system, both technical and substantive. Floor action early this year is possible, at which time supporters of hospital cost containment may try to amend the bill.

\section{Clinical Laboratories Improvement}

The bill has been ready for Senate floor action since last April, but has been held up until the House shows some interest.

\section{Emergency Medical Services}

On December 12 the President signed into law a bill reauthorizing the Emergency Medical Services program for three years. Also included in the measure is funding for the creation of a unit within HEW to administer the Sudden Infant Death Syndrome program.

\section{Alcohol, Drug Abuse Treatment and Prevention}

The Senate passed a bill extending alcohol programs for three years and another extending drug abuse programs for two years. The House agreed to one-year extensions of both programs. House and Senate staffers worked out compromise measures to renew both programs for two years. Final approval came on December 19.

\section{Nursing Training}

President Carter signed the nurse training bill in late September. However, it was only a one-year renewal of the program and the issue will be back on the agenda this year. 


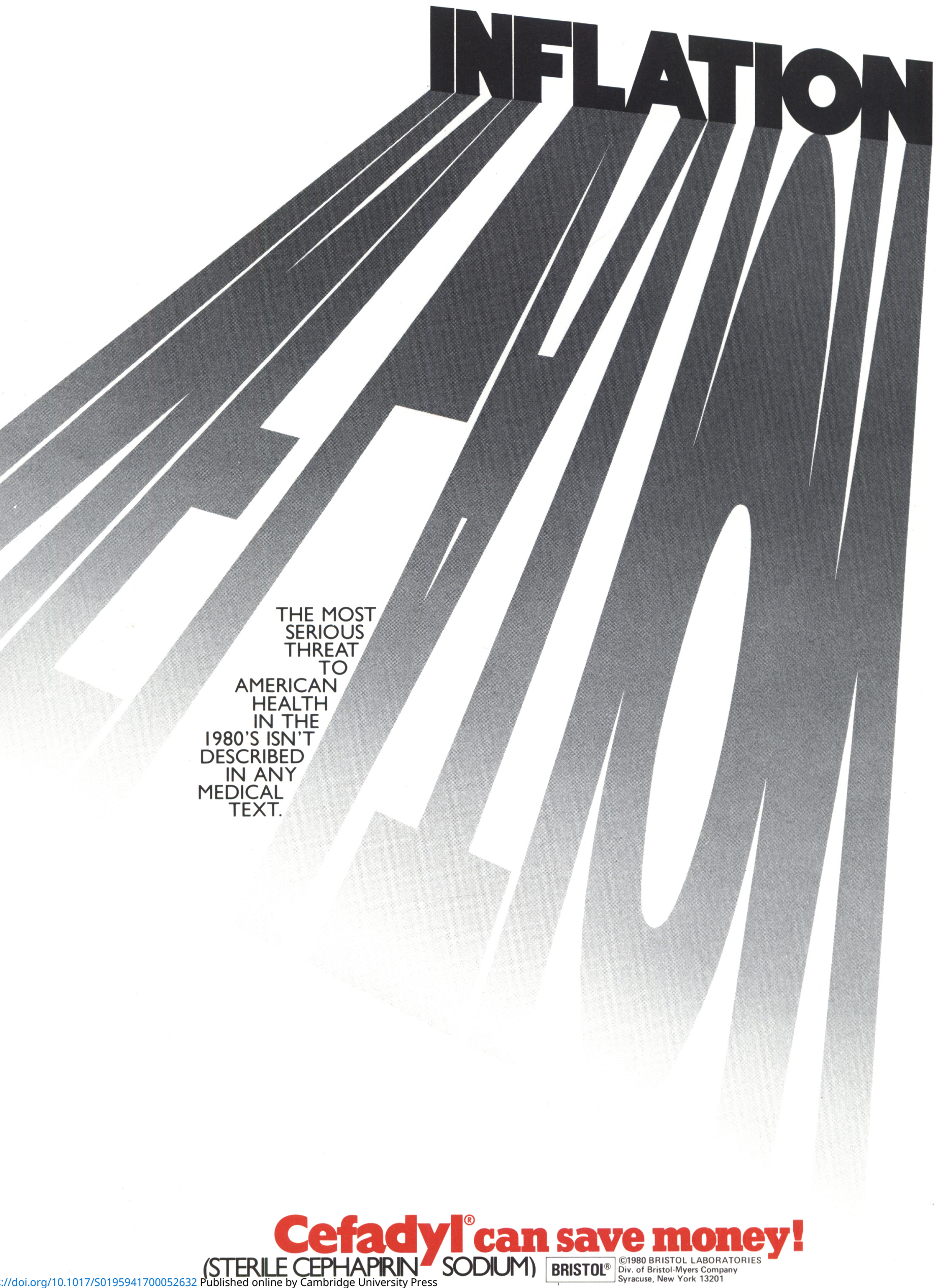






1. provides broad-spectrum, overlapping antibacterial effectiveness against common susceptible pathogens, including staph and strep

2. helps prevent topical infections, and treats those that have already started

3. it's good medicine for abrasions, lacerations, open wounds, primary pyodermas, secondarily infected dermatoses; and it's painless and cosmetically pleasing

4. contains three antibiotics that are rarely used systemically

5. you can recommend it in any of the three convenient package sizes: 1 oz tube, $1 / 2$ oz tube, or the versatile, single-use foil packet

\section{NEOSPORIN' Ointment}

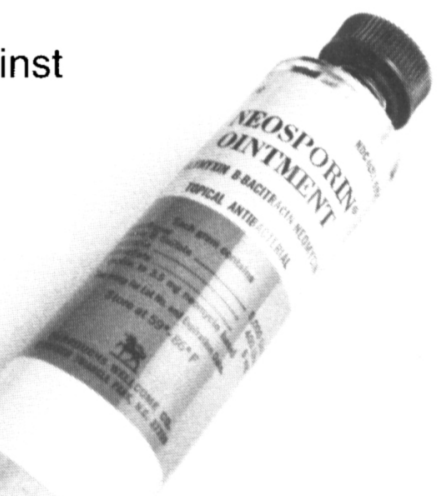

(polymyxin B-bacitracin-neomycin)

Each gram contains: Aerosporin (Polymyxin B Sulfate) 5,000 units, bacitracin zinc 400 units, neomycin sulfate $5 \mathrm{mg}$ (equivalent to $3.5 \mathrm{mg}$ neomycin base): special white petrolatum os; in tubes of $1 \mathrm{oz}$ and $1 / 2 \mathrm{oz}$ and $1 / 32 \mathrm{oz}$ (approx.) foil packets.

WARNING: Because of the potential hazard of nephrotoxicity and ototoxicity due to neomycin, care should be exercised when using this product in treating extensive burns trophic ulceration and other extensive conditions where absorption of neomycin is possible. In burns where more than 20 percent of the body surface is affected. especially if the patient has impaired renal function or is receiving other aminogiycoside antibiotics concurrently. not more than one application a day is recommended
When using neomycin-containing products to control secondary infection in the chronic dermatoses, it should be borne in mind that the skin is more liable to become sensitized to many substances, including neomycin. The manifestation of sensitization to neomycin is usually a low grade reddening with swelling, dry scaling and itching; it may be manifest simply as a failure to heal. During iongterm use of neomycin-containing products, periodic examination for such signs is advisable and the patien should be told to discontinue the product if they are observed. These symptoms regress quickly on withdrawing the medication. Neomycin-containing applications should be avoided for that patient thereafter

PRECAUTIONS: As with other antibacterial preparations. prolonged use may result in overgrowth of nonsusceptible organisms, including fungi. Appropriate measures should be taken if this occurs

ADVERSE REACTIONS: Neomycin is a not uncommon cutareous sensitizer. Articles in the current literature indicate an increase in the prevalence of persons allergic to neomycin. Ototoxicity and nephrotoxicity have been reported (see Warning section)

Complete literature available on request from Professional Services Dept. PML

Burroughs Wellcome Co.
Research Triangle Park
North Carolina 27709 